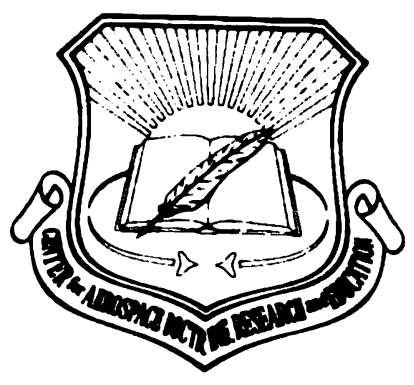

SETUP

\title{
What the Air Force Did in Vietnam and Why
}

by

Earl H. Tilford, Jr.

=

Air University Press

Maxwell Air Force Base, Alabama 36112-5532 